\title{
Diagnosis of viral central nervous system infections using antipeptide antibody against viral antigen by ELISA
}

\author{
R. I. TIWARI, S. S. BHULLAR, N. H. CHANDAK, N. N. BAHETI, H. F. DAGINAWALA, L.R. SINGH, R. S. KASHYAP*
}

Biochemistry Research Laboratory, Central India Institute of Medical Sciences, Nagpur - 440010, India

Received October 20, 2016; revised March 16, 2018; accepted September 28, 2018

\begin{abstract}
Summary. - Viral infections of the central nervous system (CNS) occur sporadically and have been extensively studied because of the potential for permanent neurological damage or death. The neurotropic viruses have been reported to lead to various CNS infections. The objective of the present study is to develop an antigen detection ELISA protocol for detection and quantification of viral antigen in CNS infections by assessing the usefulness of antipeptide antibodies against potential peptides of cytomegalovirus (CMV), Epstein-Barr virus (EBV), varicella zoster virus (VZV), Japanese encephalitis virus (JEV), dengue (DENV), West Nile virus (WNV) and Chandipura virus (CHPV). A total of 182 cerebrospinal fluid (CSF) samples from confirmed, suspected and non-viral infections of the CNS were evaluated using panels of antipeptide antibodies against synthetic peptides of viral proteins. The cases of confirmed and suspected viral infections of the CNS showed $77 \%$ and $11 \%$ positivity, respectively, for the detection of viral antigen using antipeptide against synthetic peptides of CMV, EBV, VZV and JEV. The concentration of viral antigen was also obtained by using antipeptide of respective viruses in CSF from both the groups. The viral antigen concentration was also correlated with viral load in confirmed cases of viral infection of the CNS. This study demonstrates the use of antipeptide against synthetic peptide derived from CMV, EBV, VZV and JEV in diagnostics of viral infections of the CNS using patients' CSF samples.
\end{abstract}

Keywords: viral infection of the CNS; synthetic peptide; antipeptide antibody; viral load; antigen concentration

\section{Introduction}

Viral infections of the central nervous system (CNS) may be presented with a variety of neurological symptoms, most commonly dominated by either encephalitis or meningitis, however, the incidence of these cases is ambiguous. The neurotropic viruses have been reported to lead to various CNS infections. The viral infections of the CNS occur sporadically, endemically or in outbreaks (Griffin, 2010). Among the identified pathogens, the common agents of viral CNS

*Corresponding author. E-mail: raj_ciims@rediffmail.com; phone: +91-712-2233381-2236441.

Abbreviations: $\mathrm{CHPV}=$ Chandipura virus; $\mathrm{CMV}=$ cytomegalovirus; $\mathrm{CSF}=$ cerebrospinal fluid; $\mathrm{CNS}=$ central nervous system; DENV = dengue virus; EBV = Epstein-Barr virus; JEV = Japanese encephalitis virus; $\mathrm{VZV}=$ varicella zoster virus; $\mathrm{WNV}=\mathrm{West}$ Nile virus infections are herpesviruses including cytomegalovirus (CMV), Epstein-Barr virus (EBV), varicella zoster virus (VZV), flaviviruses, including Japanese encephalitis virus (JEV), dengue virus (DENV), West Nile virus (WNV) and rhabdoviruses such as, Chandipura virus (CHPV) (Tandaleet al., 2008; Tang et al., 1997; Glaser et al., 2003, 2006). Human infections caused by herpesviruses are ubiquitous and more than $90 \%$ of adults worldwide have been infected with EBV, $\mathrm{VZV}$, and CMV before their adolescence (Macsween et al., 2003; Mueller et al., 2008; Manicklal et al., 2013). In seasonal viral infections, various outbreaks of flaviviruses such as JEV, WNV, and DNV are reported worldwide (Misra et al., 2010; Marfin et al., 2001; Pinheiro et al., 1997). Similarly, every year in high endemic regions of India flavivirus infections are reported with high fatality rates (Paramasivan et al., 2003; Varatharaj, 2010; Tiwari et al., 2012). CHPV infections are also reported in India with more than $75 \%$ mortality rate (Chadha et al., 2005). 
The diagnostics of viral infections of the CNS is always challenging, as initial neurological symptoms of many viruses are similar to different causes of CNS infections. Rapid and accurate diagnostics of viral infections of the CNS are important for antiviral treatment or epidemiological and pathological investigation. Clinical diagnosis of viral infections of the CNS is based on the neurodiagnostic test such as electroencephalogram; computerized tomography scans (CT) and magnetic resonance imaging (MRI). These tests usually establish the presence of viral infections in the CNS, but do not show the etiological cause (Whitley, 1990). Currently, laboratory diagnostics of viral infections of the CNS is based on isolation of virus from clinical samples, serological detection of virus-specific intrathecal antibody response and nucleic acid detection methods such as polymerase chain reaction (PCR) assays. Isolation of viruses is the gold standard method, but it is slow, time-consuming, expensive and requires the sophisticated laboratory. Although PCR-based methods are rapid, more sensitive and used for early and accurate diagnosis, but the high cost of the assays and requirement of specialized laboratory equipment limits its application. The detection of antibody requires 5-6 days for the patients to develop antibody response and there are issues of crossreactivity of antibody in same family members of viruses; and thus, it has less implications for early and accurate diagnosis (Ratcliff et al., 2007; Storch, 2000; Mansfield et al., 2011). Therefore, the detection of viral antigen can be an alternative to virus isolation, detection of viral nucleic acid and antibody response in the diagnostics of viral CNS infections (Kashyap et al., 2010, 2015).

Antipeptide antibody is used as a safe and specific tool in biological research for diagnostics (Saravanan et al., 2004). The present study describes a method in which antipeptide antibodies were evaluated against viral synthetic peptides for the detection of antigen in clinical samples by an in-house ELISA method. Antigenic peptide determination of respective viral proteins was carried out by using online software which uses Kolaskar and Tongaonkar method (Kolaskar et al., 1990). Total of $10 \mathrm{immunogenic} \mathrm{peptides} \mathrm{of} \mathrm{viral} \mathrm{proteins}$ namely, glycoprotein $\mathrm{B}(\mathrm{gB})$ of CMV, glycoprotein E (gE) of VZV, glycoprotein $\mathrm{E}$ ( $\mathrm{gE}$ ) of $\mathrm{WNV}$ and glycoprotein $\mathrm{G}(\mathrm{gG})$ of CHPV, early antigen-diffuse (EA-D) of EBV, premembrane protein (prM) of JEV and non-structural proteins (NS) of DENV were targeted for peptide synthesis (Haumont et al., 1996; Fox and Houghton, 1989; Britt et al., 1988; Wang et al., 2001; Cardosa et al., 2002; Jacobs et al., 2000; Cherian et al., 2012).These synthetic peptides were then used for the production of antipeptide by immunizing the rabbits against the peptides conjugated to KLH. The antipeptides were screened in clinical samples of suspected and confirmed viral infections of the CNS patients for the development of antigen-based ELISA. The purpose of the study is to detect the viral antigen using antipeptide antibodies for diagnostics of viral infections of the CNS.

\section{Material and Methods}

Patient's selection and sample collection. The CSF was drawn from patients admitted to Central India Institute of Medical Sciences, Nagpur, India with suspected viral infections of the CNS. Inclusion criteria involved the presence of fever, headache, altered mental status (low level of consciousness, behavior or personality changes) and other clinical manifestations (e.g. focal neurological deficits, seizures), cerebro-spinal fluid (CSF) findings showing a mild increase in protein, glucose often normal and mild pleocytosis. Neurological diagnostic investigations were performed during the first week of hospitalization; these investigations included bacterial staining (acid fast staining) and culturing, determination of the protein level, sugar level and cell counts in CSF and neuroimaging of the brain (CT scan and MRI). Approximately $2 \mathrm{ml}$ of CSF (by a standard lumbar puncture) from 182 patients was collected before treatment and from some of the patients whenever possible during treatment. The clinical data of patients were prospectively collected on case record forms. All the samples were stored at $-20^{\circ} \mathrm{C}$ until further analysis. Clinically, all the patients were divided as discussed below.

Confirmed viral infections of the CNS group $(n=13)$. Viral infections of the CNS were confirmed by real-time PCR assay in CSF samples.

Suspected viral infections of the CNS group $(n=104)$. This group included patients with acute onset of fever and clinical features consistent with viral encephalitis, CSF finding showed the mild increase of proteins and glucose and tested CSF samples were negative by real-time PCR.

Noninfectious neurological disorders $(n=40)$. Patients who had no evidence of CNS or extra-CNS bacterial or viral infections were grouped in the non-infectious neurological disorders group. Patients included in this group had hypertension, status epilepticus, stroke, or other disorders.

Other infectious cases $(n=25)$. Patients included in this group had tuberculous meningitis (TBM) or pyogenic meningitis. A diagnosis of TBM was based on clinical features including subacute or chronic fever with features of meningeal irritation such as a headache, neck stiffness, and vomiting, with or without other features of CNS involvement.

Ethics statement.The study was approved by the Ethical Committee of Central India Institute of Medical Sciences, (CIIMS), Nagpur (ciims/Res/02/14). An informed consent was obtained from all the patients.

Quantitative real-time PCR assay. The viral nucleic acid was extracted from CSF samples using ZR viral RNA/DNA isolation kit (Zymo research, USA). The amplification reaction was carried out for all selected viruses using the set of primers (Table 1). The amplification reactions were carried out in a total volume of 
Table 1. Oligonucleotide primers for all the viruses

\begin{tabular}{|c|c|c|c|}
\hline Sr. No. & Virus & References & Primer sequence \\
\hline \multirow[t]{2}{*}{1} & CMV & Schaade et al., 2000 & F-CCGCAACCTGGTGCCCATGG \\
\hline & & & R-CGTTTGGGTTGCGCAGCGGG \\
\hline \multirow[t]{2}{*}{2} & EBV & Huang et al., 2004 & F-CAGTGCCTCCGCCTGAGCCGCT \\
\hline & & & R- GGTCAGATTTTGCAATATATTT \\
\hline \multirow[t]{2}{*}{3} & VZV & Huang et al; 2004 & F-TTAGTCCGCGCGGCCATGAATC \\
\hline & & & R-ATAAAACCTCCTCTAGGACATG \\
\hline \multirow[t]{2}{*}{4} & JEV & Santhosh et al., 2007 & F-AGAGCGGGGAAAAAGGTCAT \\
\hline & & & R-TTTCACGCTCTTTCTACAGT \\
\hline \multirow[t]{2}{*}{5} & WNV & Parida et al., 2004 & F-TGGATTTGGTTCTCGAAGG \\
\hline & & & R-GGTCAGCACGTTTGTCATT \\
\hline \multirow[t]{6}{*}{6} & $\operatorname{DENV}(1,2,3,4)$ & Lanciotti et al., 1992 & D1-TCAATATGCTGAAACGCGCGAGAAACCG \\
\hline & & & D2-TTGCACCAACAGTCAATGTCTTCAGGTTC \\
\hline & & & 'TS1 5'-CGTCTCAGTGATCCGGGGG-3' \\
\hline & & & 'TS2 5'-CGCCACAAGGGCCATGAACAG-3' \\
\hline & & & TS3 5'-TAACATCATCATGAGACAGAGC-3' \\
\hline & & & 'TS4 5'-CTCTGTTGTCTTAAACAAGAGA-3' \\
\hline \multirow[t]{2}{*}{7} & CHPV & Chadha et al., 2005 & F-GAGAATGCGACCAGTCTTAT \\
\hline & & & R-TGCAAGTTCGAGACCTTCCAT \\
\hline
\end{tabular}

$10 \mu \mathrm{l}$, containing $1 \mu \mathrm{l}$ of template DNA and cDNA (SuperScript ${ }^{\oplus}$ III First-strand synthesis system, Invitrogen, USA), $5 \mu$ l of Power $\mathrm{SYBR}^{\oplus}$ Green PCR master mix (Applied Biosystems, USA), $1 \mu \mathrm{l}$ each of $(0.5 \mu \mathrm{mol} / \mathrm{l})$ forward and reverse primer (Sigma, US), and $2 \mu \mathrm{l}$ of sterile water. The amplification conditions consisted of preincubation at $95^{\circ} \mathrm{C}$ for $10 \mathrm{~min}$ and two steps ( 40 cycles) at $95^{\circ} \mathrm{C}$ for $15 \mathrm{~s}$ and $60^{\circ} \mathrm{C}$ for $1 \mathrm{~min}$ for $\mathrm{CMV}, \mathrm{EBV}, \mathrm{VZV}$ virus, $55^{\circ} \mathrm{C}$ for $\operatorname{DENV}(1,2,3,4) \mathrm{JEV}, \mathrm{WNV}$ and CHPV. The quantification cycle $(\mathrm{Ct})$ was calculated as the cycle number at which the concentration increase became exponential. A negative control was also included in PCR assay.

Antipeptide production. Synthetic peptides of $95 \%$ purity as determined by mass spectrometry and HPLC were used for the production of antipeptide. Rabbits were immunized with synthetic peptides (Table 2) conjugated to KLH. The antibodies were affinity purified with the Protein A affinity matrix and then dialyzed against PBS buffer. The anti-peptide was custom synthesized from Hongkong GenicBio Tech Co., Limited.

ELISA. One hundred microliters of CSF dilutions (1:5) from viral CNS infected patients was added to the microtiter plates. The plates were incubated at $37^{\circ} \mathrm{C}$ for $90 \mathrm{~min}$. Blocking with $0.5 \% \mathrm{BSA}$ in PBS was done for $45 \mathrm{~min}$ at $37^{\circ} \mathrm{C}$. After antipeptide washing with PBS, antibodies (1:10,000 dilutions) were added and the plates were incubated at $37^{\circ} \mathrm{C}$ for $45 \mathrm{~min}$. After incubation, the wells were washed and goat anti-rabbit IgG-horseradish peroxidase secondary antibody (Bangalore Genei. India) was added (1:10,000 dilution). The wells were then incubated for $45 \mathrm{~min}$ at $37^{\circ} \mathrm{C}$. After another wash with PBS, $100 \mu$ of the TMB- $\mathrm{H}_{2} \mathrm{O}_{2}$ substrate solution (Science Products Inc., USA) was added to the wells and incubated at room temperature for approximately $10 \mathrm{~min}$. The reaction was then stopped with $100 \mu \mathrm{l}$ of $2.5 \mathrm{~N} \mathrm{H}_{2} \mathrm{SO}_{4}$. The absorbance in each well was measured at $450 \mathrm{~nm}$. Negative reference control was selected

Table 2. List of viral proteins and their peptide sequences used for the production of antipeptides

\begin{tabular}{lllll}
\hline Sr. No. & Viruses & Viral proteins & Peptides sequence & Antipeptide \\
\hline 1 & CMV & glycoprotein B & RSSNVED & A5 \\
2 & EBV & early antigen D & TASSLQK & B3 \\
3 & VZV & glycoprotein E & SVYEPYYHSD & D2 \\
4 & DENV-1 & nonstructural protein NS1 & EEGVCGI & D3 \\
5 & DENV-2 & nonstructural protein NS2 & ITPELNH & D5 \\
6 & DENV-3 & nonstructural protein NS3 & SPKRLATAI & SSEVCDH \\
7 & DENV-4 & nonstructural protein NS4 & GESSLVN & E3 \\
8 & JEV & pre-membrane protein prM & GEVTVDC & IDGPVLK \\
9 & WNV & glycoprotein E & & G3 \\
\hline
\end{tabular}


Table 3. Mean \pm SD, absorbance and p-value with cut-off value determined by ROC analysis of antipeptide

\begin{tabular}{|c|c|c|c|c|c|c|}
\hline \multirow{2}{*}{ Viruses } & \multirow{2}{*}{ Antipeptide } & Test $(n=117)$ & Control $(n=65)$ & \multirow{2}{*}{ p-value } & \multirow{2}{*}{ Cut-off value } & \multirow{2}{*}{$\begin{array}{l}\text { 95\% confidence } \\
\text { interval }\end{array}$} \\
\hline & & \multicolumn{2}{|c|}{ Mean \pm SD } & & & \\
\hline $\mathrm{CMV}$ & A5 & $0.34 \pm 0.08$ & $0.25 \pm 0.09$ & $<0.0001$ & $>0.247$ & 0.687 to 0.822 \\
\hline EBV & B3 & $0.36 \pm 0.18$ & $0.27 \pm 0.12$ & $<0.0001$ & $>0.223$ & 0.625 to 0.770 \\
\hline VZV & $\mathrm{C} 2$ & $0.36 \pm 0.17$ & $0.25 \pm 0.09$ & $<0.0001$ & $>0.243$ & 0.666 to 0.805 \\
\hline DENGUE1 & D2 & $0.32 \pm 0.07$ & $0.25 \pm 0.09$ & $<0.0001$ & $>0.236$ & 0.634 to 0.777 \\
\hline DENGUE2 & D3 & $0.33 \pm 0.08$ & $0.26 \pm 0.09$ & $<0.0001$ & $>0.287$ & 0.641 to 0.783 \\
\hline DENGUE 3 & D5 & $0.32 \pm 0.07$ & $0.25 \pm 0.09$ & $<0.0001$ & $>0.227$ & 0.625 to 0.770 \\
\hline DENGUE 4 & D8 & $0.33 \pm 0.07$ & $0.25 \pm 0.09$ & $<0.0001$ & $>0.243$ & 0.660 to 0.800 \\
\hline JEV & E3 & $0.36 \pm 0.14$ & $0.25 \pm 0.10$ & $<0.0001$ & $>0.302$ & 0.681 to 0.818 \\
\hline WNV & $\mathrm{F} 1$ & $0.21 \pm 0.07$ & $0.22 \pm 0.07$ & 0.3570 & $>0.247$ & 0.649 to 0.791 \\
\hline CHPV & G3 & $0.20 \pm 0.10$ & $0.18 \pm 0.10$ & 0.1977 & $>0.251$ & 0.640 to 0.783 \\
\hline
\end{tabular}

from pooled CSF of non-viral infections of the CNS patients and viral synthetic peptides were used as positive reference control. The positive CSF control, negative CSF control and sample blank (PBS) were used as controls. Three replicates of positive and negative controls were included in each ELISA plate along with the test sample.

Standard curve ELISA for antigen concentration estimation. Viral peptides of respective viruses were used as a standard for the generation of the calibration curve. These standards were diluted with CSF of non-viral infected patients and assayed at the same time as the specimens. The absorbance $\log \mathrm{A}_{450}$ was plotted vs. $\log$ peptide concentration and concentrations in each specimen were calculated from the calibration curve.

Statistical analysis. All statistical analyses were performed using MedCalc software (version 10.1. 2). The selection of cut-off point was performed with a Receiver Operating Characteristic Curve (ROC) analysis and p-value of $<0.05$ was considered statistically significant.

\section{Results}

The CSF samples of 117 patients admitted to the neurological department of a tertiary care centre with suspected viral encephalitis were collected during a 2 year period and categorized into suspected viral CNS infection and confirmed viral infections of the CNS groups based on PCR assay results, clinical history, biochemical, microbiological and pathological analysis and neuroimaging observations. Evaluations of all CSF samples were done for the detection of viral antigen using antipeptide antibodies in an ELISA protocol. A total of 10 antipeptides were synthesized against immunogenic proteins of selected viruses and then used for detection of viral antigen (Table 2).

Mean \pm SD value of absorbance of all the antipeptides used for detection of viral antigen in CSF samples of confirmed and suspected viral infections of the CNS cases and control groups as determined by indirect ELISA along with their p-value and cut-off value were determined by ROC analysis (Table 3). The significant $\mathrm{p}$-values $(\mathrm{p}<0.0001)$ were obtained for antipeptide of A5, B3, C2, D2, D3, D5, D8, E3 against the synthetic peptide of CMV, EBV, VZV, DENV $(1,2,3,4$ serotypes) and JEV, respectively. However, no significant pvalue was obtained for WNV and CHPV antipeptide.

The total positivity of viruses by antigen ELISA in all the selected patient groups, namely, confirmed, suspected, noninfectious neurological disorder and other infectious cases are shown in Table 4 . A positivity of $77 \%$ was obtained in confirmed cases. Out of 13 confirmed cases by PCR for EBV, VZV and JEV, a total of 10 cases were positive by antigen ELISA. Two cases each were positive for EBV and VZV and 6 cases were positive for JEV. Similarly, in 104 cases of suspected viral CNS infections, 11 cases were positive for viral antigen. Out of these 11 cases, 1 case was positive for CMV, 5 for EBV, 2 for VZV and 3 for JEV. Therefore, a total of 21 cases showed

Table 4. Total positivity of viruses in viral CNS infection cases by antigen detection ELISA

\begin{tabular}{|c|c|c|c|c|c|c|c|c|}
\hline Category of samples & CMV & EBV & VZV & JEV & $\begin{array}{c}\text { DENV } \\
(1,2,3,4)\end{array}$ & WNV & CHPV & $\begin{array}{c}\text { Total positivity } \\
\text { of viruses }\end{array}$ \\
\hline Confirmed viral CNS infections $(\mathrm{n}=13)$ & 0 & 2 & 2 & 6 & 0 & 0 & 0 & $77 \%$ \\
\hline Suspected viral CNS infections $(\mathrm{n}=104)$ & 1 & 5 & 2 & 3 & 0 & 0 & 0 & $11 \%$ \\
\hline Non-infectious neurological disorder $(\mathrm{n}=40)$ & 0 & 0 & 0 & 0 & 0 & 0 & 0 & $0 \%$ \\
\hline Other infectious cases $(n=25)$ & 0 & 0 & 0 & 0 & 0 & 0 & 0 & $0 \%$ \\
\hline
\end{tabular}




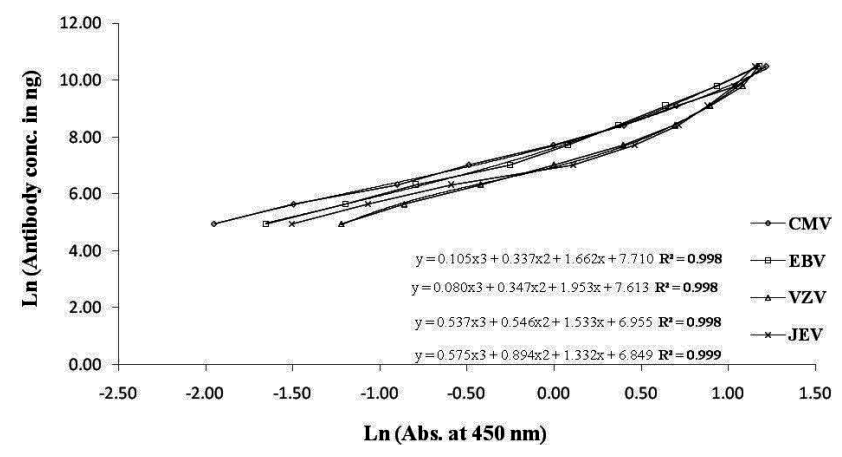

Fig. 1

ELISA standard curve with a regression equation for the determination of antigen concentration using antipeptide

positivity for viral antigen in CSF by antigen ELISA. In noninfectious neurological disorder and other infectious cases, no positivity was obtained for viral antigen in CSF samples of patients suggesting no cross-reactivity by the antipeptides.

Table 5 shows concordance for the diagnosis of viral CNS infections by both antigen ELISA and real-time PCR assay. Only 1 case was positive for CMV in the PCR-negative group and thus $88 \%$ concordance was obtained for CMV. Similarly, for EBV and VZV, $86 \%$ and $89 \%$ concordance was achieved between both the tests, respectively. The highest

Table 5. Concordance between antigen ELISA and PCR

\begin{tabular}{lccc}
\hline Antigen ELISA & $\begin{array}{c}\text { PCR positive } \\
(\mathbf{n}=\mathbf{1 3})\end{array}$ & $\begin{array}{c}\text { PCR negative } \\
(\mathbf{n}=\mathbf{1 0 4})\end{array}$ & $\begin{array}{c}\text { Concordance } \\
(\%)\end{array}$ \\
\hline CMV positive $(\mathrm{n}=1)$ & 0 & 1 & 88 \\
CMV negative $(\mathrm{n}=116)$ & 13 & 103 & 86 \\
\hline EBV positive $(\mathrm{n}=7)$ & 2 & 5 & \\
EBV negative $(\mathrm{n}=110)$ & 11 & 99 & 89 \\
\hline VZV positive $(\mathrm{n}=4)$ & 2 & 2 & 92 \\
VZV negative $(\mathrm{n}=113)$ & 11 & 102 & 88 \\
\hline JEV positive $(\mathrm{n}=8)$ & 6 & 2 & 88 \\
JEV negative $(\mathrm{n}=109)$ & 7 & 102 & \\
\hline DENV positive $(\mathrm{n}=0)$ & 0 & 0 & 88 \\
DENV negative $(\mathrm{n}=117)$ & 13 & 104 & \\
\hline WNV positive $(\mathrm{n}=0)$ & 0 & 0 & \\
WNV negative $(\mathrm{n}=117)$ & 13 & 104 & \\
\hline CHPV positive $(\mathrm{n}=0)$ & 0 & 0 & \\
CHPV negative $(\mathrm{n}=117)$ & 13 & 104 & \\
\hline
\end{tabular}

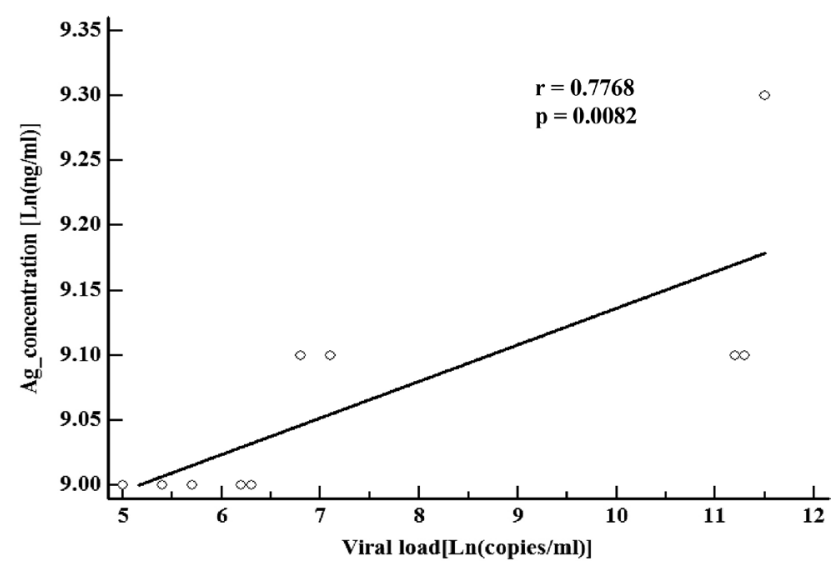

Fig. 2

Correlation between concentration of viral antigen and viral DNA in CSF of confirmed cases

agreement of $92 \%$ was achieved between both tests in JEV cases. In cases of DENV $(1,2,3,4) \mathrm{WNV}$ and CHPV the concordance was $88 \%$.

The mean antigen concentration against A5, B3, C2 and E3 antipeptide of CMV, EBV, VZV and JEV in CSF of confirmed and suspected viral infections of the CNS groups were also comparable (Table 6). In suspected cases of viral infections of the CNS higher concentrations of viral antigen were detected for EBV and VZV as compared to confirmed cases where as, higher level of JEV was detected by PCR confirmed cases. The concentration of viral antigen in CSF samples of patients was determined by plotting the standard curve. A standard curve was obtained by using the different concentrations of synthetic peptides and particular dilutions of respective antipeptides. The sample assay values were determined from the absorbance using regression equations of the standard curve (Fig. 1).

The quantity of viral antigen as determined by ELISA using antipeptides and known viral load of PCR-positive samples were subjected to correlation plot (Fig. 2) and the correlation of amount of viral antigen $\left(\log _{10} \mathrm{ng} / \mathrm{ml}\right)$ and viral $\operatorname{load}\left(\log _{10}\right.$ copies $/ \mathrm{ml}$ ) revealed significant $\mathrm{p}$-value, correlation coefficient $(\mathrm{p}=0.0082, \mathrm{r}=0.7768)$ and $95 \%$ confidence interval. The load of viral DNA in clinical samples was determined by real-time PCR assay and it varied from $1.5 \times 10^{2}-1.1 \times 10^{5}$ copies $/ \mathrm{ml}$ of CSF samples for respective viruses.

Table 6. Comparison of concentration of viral antigen in antigen ELISA positive samples

\begin{tabular}{|c|c|c|c|c|c|c|c|c|}
\hline \multirow{2}{*}{ Subjects } & \multicolumn{4}{|c|}{ Range (ng/ml) } & \multicolumn{4}{|c|}{ Mean antigen $(\mathrm{ng} / \mathrm{ml})$} \\
\hline & CMV & EBV & VZV & JEV & CMV & EBV & VZV & JEV \\
\hline Confirmed viral CNS infection cases $(n=10)$ & 0 & $8964-9380$ & $8130-8678$ & $7839-10728$ & 0 & 9172 & 8404 & 8682 \\
\hline Suspected viral CNS infection cases $(\mathrm{n}=11)$ & 8791 & $8686-12000$ & 8914-13154 & $7886-8410$ & 8791 & 9765 & 11034 & 8152 \\
\hline
\end{tabular}




\section{Discussion}

Viral infection of the CNS may result in severe disability and even death of the patients if it remains undiagnosed for a longer time. An accurate identification of viral etiology is essential for better treatment and management of patients and also to reduce the mortality and morbidity. Currently, the diagnostics of viral infections of the CNS by most laboratories is based on a few basic methods such as viral isolation and identification, nucleic acid amplification assay (RT-PCR) and detection of antibody response. Viral culturing is recognized as a gold standard, but it is difficult to isolate some of the viruses from clinical specimens because of low viremia. The molecular diagnostic tests are rapid and standard, but poses certain intrinsic disadvantages as, time-consuming and labour demanding which prevent their acceptance for routine diagnostics. Although the serological diagnostics such as antibody detection has little diagnostic value as it can generate false-positive or false-negative result when two or more flaviviruses are circulating (Storch, 2000; Ratcliff et al., 2007; Mansfield et al., 2011). A single serological method is merely indicative of recent infection and cannot be used for the diagnosis of acute infections. Therefore, a more simple and rapid method is required for detection of viral etiology which is helpful for early administration of antiviral therapy. The antigen detection ELISA has attracted more attention amongst the other serological methods as it can serve as a marker during acute viral infections for early diagnostics (Desai et al., 1994; Shukla et al., 2009; Kashyap et al., 2010, 2015; Kumar et al., 2011).

In the present study, we developed a simple and rapid in-house antigen detection ELISA method using antipeptide antibodies against a potent peptide of the immunogenic protein of respective viruses for diagnostics of viral infections of the CNS. In suspected cases of viral infections of the CNS, antigen detection is an alternative to the other methods. This method was evaluated in the CSF collected from suspected cases of viral infections of the CNS and PCR-confirmed cases. Some limited studies have been reported based on the evaluation of antipeptide antibody for antigen detection in the clinical samples for the diagnostics of viral and other infections (Saravanan et al., 2004; Kashyap et al., 2015).

The data demonstrate the assessment of antigen detection assay on the basis of the indirect ELISA method for the detection of viral antigen in CSF samples of viral encephalitis patients with additional information on the estimation of antigen concentration. In our study, out of 104 cases, negative in PCR, approximately 11 cases were positive in antigen ELISA for CMV, EBV, VZV and JEV. The observations prove that antipeptide antibodies have the ability to detect viral antigen in highly suspected cases of viral encephalitis where PCR of the CSF is negative. Some studies in India have also reported the significance of antigen detection ELISA in CSF for diagnostics of viral infections (Kashyap et al., 2010, 2015; Kumar et al., 2011; Desai et al., 1994; Shukla et al., 2009). None of the samples from non-infectious neurological disorder and other infectious groups showed viral etiology. We believe that the antipeptide based ELISA may also be used to detect viral antigen in an acute phase of illness when PCR is negative. Thus, it can also help in identification of viral etiology in outbreaks in the endemic region of India where two or more flaviviruses are circulating.

The antigen detection ELISA revealed good correlation with real-time PCR as the antigen concentration obtained using antipeptide in ELISA correlated well with viral DNA load. There have been some studies reporting the correlation of antigen concentration with viral load in the diagnostics of viral infections of the CNS (Kashyap et al., 2015; Marchetti et al., 2011; Sutthent et al., 2003). Therefore, the correlation between antigen ELISA and PCR suggested that the viral copies in CSF are proportional to the concentration of viral antigen and hence can be used as a viral load marker. Additionally, there are some advantages of antigen ELISA assay as compared with continuation of viral nucleic acid by PCR, including, sample preparation, which is simpler, and the test can be performed with equipment already available in most laboratories at a considerably low cost.

The antigen detection assay, which we have developed in our laboratory also measures the level of viral protein in CSF samples which is helpful in the earlier stage of infection. Moreover, the antigen ELISA has some advantage over nucleic acid amplification assay as it is simple and provides a quantitative analysis. The results indicate that the antipeptide antibody can be used as a powerful tool for detection of viral antigen. However, our study has some limitation as our institute is a tertiary care centre and a limited number of patients are included, therefore, further work is also needed on a much larger population. In summary, the antigen detection assay may not only be useful in initial screening purpose of viral infections of the CNS but also useful in highly suspected cases of viral infection. The assay is rapid, cost-effective and may be useful as an efficient tool for clinical diagnostics, quantification and surveillance of viral infection especially in developing countries.

Acknowledgment. All authors would like to acknowledge Central India Institute of Medical Sciences (CIIMS), Nagpur for funding the study.

\section{References}

Britt WJ, Vugler L, Stephens EB (1988): Induction of complementdependent and-independent neutralizing antibodies by recombinant-derived human cytomegalovirus gp55-116 (gB). J. Virol. 62, 3309-3318. 
Cardosa MJ, Wang SM, Sum MS, Tio PH (2002): Antibodies against prM protein distinguishes between previous infection with Dengue and Japanese encephalitis viruses. BMC Microbiol. 2, 9. https://doi.org/10.1186/1471-2180-2-9

Chadha MS, Arankalle VA, Jadi RS, MV, Thakare JP, Mahadev PV, Mishra AC (2005): An outbreak of Chandipura virus encephalitis in the eastern districts of Gujarat state, India. Am. J. Trop. Med. Hyg. 73, 566-570. https://doi. org/10.4269/ajtmh.2005.73.566

Cherian SS, Gunjikar RS, Banerjee A, Kumar S, Arankalle VA (2012): Whole genomes of Chandipura virus isolates and comparative analysis with other rhabdoviruses. PlosOne 7, e30315.

Desai A, Chandramuki A, Gourie-Devi M, Ravi V (1994): Detection of Japanese encephalitis virus antigens in the CSF using monoclonal antibodies. Clin. Diagn.Virol. 2, 191-199. https://doi.org/10.1016/0928-0197(94)90022-1

Griffin DE (2010): Emergence and re-emergence of viral diseases of the central nervous system. Prog. Neurobiol. 95-101. https://doi.org/10.1016/j.pneurobio.2009.12.003

Glaser CA, Gilliam S, Schnurr D, Forghani B, Honarmand S, Khetsuriani N, Fischer M, Cossen CK, Anderson LJ (2003): In search of encephalitis etiologies: diagnostic challenges in the California Encephalitis Project, 1998-2000. Clin. Infect. Dis. 36, 731-742. https://doi.org/10.1086/367841

Glaser CA, Honarmand S, Anderson LJ, Schnurr DP, Forghani B, Cossen CK, Schuster FL, Christie LJ, Tureen JH (2006): Beyond viruses: clinical profiles and etiologies associated with encephalitis. Clin. Infect. Dis. 43, 1565-1577. https:// doi.org/10.1086/509330

Haumont M, Jacquet A, Massaer M, Deleersnyder V, Mazzu P, Bollen A (1996): Purification, characterization and immunogenicity of recombinant Varicella-Zoster virus glycoprotein gE secreted by Chinese hamster ovary cells. Virus Res. 40, 199. https://doi.org/10.1016/01681702(95)01270-2

Huang C, Morse D, Slater B, Anand M, Tobin E, Smith P, Dupuis M, Hull R, Ferrera R, Rosen B, Grady L (2004): Multipleyear experience in the diagnosis of viral central nervous system infections with a panel of polymerase chain reaction assays for detection of 11 viruses. Clin. Infect. Dis. 39, 630-635. https://doi.org/10.1086/422650

Jacobs MG, Robinson PJ, Bletchly C, Mackenzie JM, Young PR (2000): Dengue virus nonstructural protein 1 is expressed in a glycosyl-phosphatidylinositol-linked form that is capable of signal transduction. FASEB J. 14, 1603-1610. https://doi.org/10.1096/fi.99-0829com

Kashyap RS, Bhullar SS, Chandak NH, Purohit HJ, Taori GM, Daginawala HF (2015): Diagnosis of herpes simplex encephalitis by ELISA using antipeptide antibodies against type-common epitopes of glycoprotein B of herpes simplex viruses. J. Immun. Immunochem. 37, 1-11.

Kashyap RS, Morey SH, Chandak NH, Purohit HJ, Taori GM, Daginawala HF(2010): Detection of viral antigen, IgM and IgG antibodies in cerebrospinal fluid of Chikungunya patients with neurological complications. Cerebrospinal Fluid Res.13, 7-12. https://doi.org/10.1186/1743-8454$\underline{7-12}$
Kolaskar, AS, Tongaonkar PC (1990): A semi-empirical method for prediction of antigenic determinants on protein antigens. FEBS Lett. 276, 172-174. https://doi.org/10.1016/00145793(90)80535-Q

Kumar JS, Parida M, Rao PV (2011): Monoclonal antibody-based antigens capture immunoassay for detection of circulating non-structural protein NS1: implications for early diagnosis of Japanese encephalitis virus infection. J. Med. Virol. 83, 1063-1070. https://doi.org/10.1002/jmv.22097

Lanciotti RS, Calisher CH, Gubler DJ, Chang GJ, Vorndam AV (1992): Rapid detection and typing of dengue viruses from clinical samples by using reverse transcriptase-polymerase chain reaction. J. Clin. Microbiol. 30, 545-551.

Macsween KF, Crawford DH (2003): Epstein-Barr virus-recent advances. Lancet Infect. Dis. 3, 131-140. https://doi. org/10.1016/S1473-3099(03)00543-7

Manicklal S, Emery VC, Lazzarotto T, Boppana SB, Gupta RK (2013): The "silent" global burden of congenital cytomegalovirus. Clin. Microbiol. Rev. 26, 86-102. https:// doi.org/10.1128/CMR.00062-12

Mansfield KL, Horton DL, Johnson N, Li L, Barrett AD, Smith DJ, Galbraith SE, Solomon T, Fooks AR (2011): Flavivirusinduced antibody cross-reactivity. J. Gen. Virol. 92, 2821-2829. https://doi.org/10.1099/vir.0.031641-0

Marchetti S, Santangelo R, Manzara S, D'onghia S, Fadda G, Cattani $P$ (2011): Comparison of real-time PCR and pp65 antigen assays for monitoring the development of Cytomegalovirus disease in recipients of solid organ and bone marrow transplants. New Microbiol. 34, 157-164.

Marfin AA, Gubler DJ (2001): West Nile encephalitis: an emerging disease in the United States. Clin. Infect. Dis. 33, 1713-1719. https://doi.org/10.1086/322700

Misra UK, Kalita J (2010): Overview: Japanese encephalitis. Prog. Neurobiol. 91, 108-120. https://doi.org/10.1016/j.pneurobio.2010.01.008

Mueller NH, Gilden DH, Cohrs RJ, Mahalingam R, Nagel MA (2008): Varicella zoster virus infection: clinical features, molecular pathogenesis of disease, and latency. Neurol. Clin. 26, 675-697. https://doi.org/10.1016/j. ncl.2008.03.011

Paramasivan R, Mishra AC, Mourya DT (2003): West Nile virus: the Indian scenario. Indian J. Med. Res. 118, 101-108.

Parida M, Posadas G, Inoue S,Hasebe F, Morita K (2004): Realtime reverse transcription loop-mediated isothermal amplification for rapid detection of West Nile virus. J. Clin. Microbiol. 42, 257-263. https://doi.org/10.1128/ LCM.42.1.257-263.2004

Pinheiro FP, Corber SJ (1997): Global situation of dengue and dengue hemorrhagic fever, and its emergence in the Americas. World Health Stat. Q. 50, 161-169.

Ratcliff RM, Chang G, Kok T, Sloots TP (2007): Molecular diagnosis of medical viruses. Curr. Issues Mol. Biol. 9, 87-102.

Fox RI, Houghton R (1989): Synthetic polypeptides and antibodies related to Epstein-Barr virus early antigen-diffuse. United States Patent. Patent No. US 04879213.

Santhosh SR, Parida MM, Dash PK, Pateriya A, Pattnaik B, Pradhan HK, Tripathi NK, Ambuj S, Gupta N, Saxena P, Lakshmana Rao PV (2007): Development and evaluation of 
SYBR Green I-based one-step real-time RT-PCR assay for detection and quantitation of Japanese encephalitis virus. J. Virol. Methods 143, 73-80. https://doi.org/10.1016/j. jviromet.2007.02.011

Saravanan P, Satishkumar, Kataria JM, Rasool TJ (2004): Detection of infectious bursal disease virus by ELISA using an antipeptide antibody raised against VP3 region. Acta Virol. 48, 39-45.

Schaade L, Kockelkorn P, Ritter K, Kleines M (2000): Detection of cytomegalovirus DNA in human specimens by Light Cycler PCR. J. Clin. Microbiol. 38, 4006-4009.

Shukla J, Khan M, Tiwari M, Sannarangaiah S, Sharma S, Rao PV, Parida M (2009): Development and evaluation of antigen capture ELISA for early clinical diagnosis of Chikungunya. Diagn. Microbiol. Infect. Dis. 65, 142-149. https:// doi.org/10.1016/j.diagmicrobio.2009.06.017

Storch GA (2000): Diagnostic virology. Clin. Infect. Dis. 31, 739-751. https://doi.org/10.1086/314015

Sutthent R, Gaudart N, Chokpaibulkit K, Tanliang N, Kanoksinsombath C, Chaisilwatana P (2003): p24 antigen detection assay modified with a booster step for diagnosis and monitoring of human immunodeficiency virus type 1 infection. J. Clin. Microbiol. 41, 1016-1022. https://doi. org/10.1128/JCM.41.3.1016-1022.2003
Tandale BV, Tikute SS, Arankalle VA, Sathe PS, Joshi MV, Ranadive SN, Kanojia PC, Eshwarachary D, Kumarswamy M, Mishra AC (2008): Chandipura virus: a major cause of acute encephalitis in children in North Telangana, Andhra Pradesh, India. J. Med. Virol. 80, 118-124. https://doi. org/10.1002/jmv.21041

Tang YW, Espy MJ, Persing DH, Smith TF (1997): Molecular evidence and clinical significance of herpesvirues coinfection in the central nervous system. J. Clin. Microbiol. $35,2869-2872$.

Tiwari S, Singh RK, Tiwari R, Dhole TN (2012): Japanese encephalitis: a review of the Indian perspective. Braz. J. Infect. Dis. 16, 564-173. https://doi.org/10.1016/j.bjid.2012.10.004

Varatharaj A (2010): Encephalitis in the clinical spectrum of dengue infection. Neurol. India 58, 585-591. https://doi. org/10.4103/0028-3886.68655

Wang T, Anderson JF, Magnarelli LA, Bushmich S, Wong S, Koski RA (2001): West Nile virus envelope protein: role in diagnosis and immunity. Ann. N. Y. Acad. Sci. 951, 325-327. https://doi.org/10.1111/j.1749-6632.2001.tb02708.x

Whitley RJ (1990): Viral encephalitis. N. Engl. J. Med. 323, 242-250. https://doi.org/10.1056/NEJM199007263230406. 